\title{
Incentives and social relationships of hunters and traders in a Liberian
} bushmeat system

Jones, Sorrel; Papworth, Sarah; Keane, Aidan; St John, Freya; Smith, Emmanuel; Flomo, Abraham; Nyamunue, Zuannah; Vickery, Juliet

\section{Biological Conservation}

DOI:

10.1016/j.biocon.2019.06.006

Published: 01/09/2019

Peer reviewed version

Cyswllt i'r cyhoeddiad / Link to publication

Dyfyniad o'r fersiwn a gyhoeddwyd / Citation for published version (APA):

Jones, S., Papworth, S., Keane, A., St John, F., Smith, E., Flomo, A., Nyamunue, Z., \& Vickery, $J .(2019)$. Incentives and social relationships of hunters and traders in a Liberian bushmeat system. Biological Conservation, 237, 338-347. https://doi.org/10.1016/j.biocon.2019.06.006

\footnotetext{
Hawliau Cyffredinol / General rights

Copyright and moral rights for the publications made accessible in the public portal are retained by the authors and/or other copyright owners and it is a condition of accessing publications that users recognise and abide by the legal requirements associated with these rights.

- Users may download and print one copy of any publication from the public portal for the purpose of private study or research.

- You may not further distribute the material or use it for any profit-making activity or commercial gain

- You may freely distribute the URL identifying the publication in the public portal?
}

Take down policy

If you believe that this document breaches copyright please contact us providing details, and we will remove access to the work immediately and investigate your claim. 


\title{
Incentives and social relationships of hunters and traders in a Liberian bushmeat system
}

\author{
Abstract \\ Hunting provides livelihoods and food security for a large number of people across the \\ tropics but endangers wildlife populations. Effective management requires understanding \\ both social and economic dynamics of local bushmeat systems, yet social elements such as \\ relationships between actors are often overlooked. We provide the first detailed description of \\ a rural hunting system in Liberia, from interviews with 205 hunters and 50 traders in the Gola \\ Forest. We found bushmeat contributed substantially to local livelihoods and earnings from \\ hunting and trading were high relative to local alternatives (median US\$120 and
} \$US262/month, hunters and traders respectively). Most of hunters' catch was sold to traders (85\% of harvested biomass) and subsequently transported to urban markets (65\% of all harvested biomass). Local consumption accounted for $27 \%$ of total harvest. Financial risks from meat confiscation were primarily born by traders, many of whom were women, and $60 \%$ perceived this as a motivation to reduce trading. By contrast, the most commonly stated motivation to reduce hunting was the time demanded by alternative activities such as farming. This discrepancy implies that livelihood support initiatives and law enforcement tools may play distinct roles across groups. Relationships between hunters and traders were complex and involved a variety of credit arrangements. Interpersonal trust played an important role, with mistrust of hunters being cited by $12 \%$ of traders as the principle barrier for profiting from bushmeat trade. Our findings provide context for designing conservation strategies and suggest that underlying social processes deserve closer attention in bushmeat research.

\section{Introduction}

Over-harvesting of wildlife for human consumption is a problem for wildlife populations and the humans who depend on them. Hunting provides a valuable source of income and food for a large number of people living around tropical forests (Cawthorn and Hoffman, 2015) but is unsustainable at current levels (Benítez-López et al., 2017) and puts species at risk of extinction (Milner-Gulland et al., 2002; Oates et al., 2010). A good understanding of both the social and ecological elements of hunting systems is needed to develop effective tools to address this problem (Dorward, 2014; Milner-Gulland, 2012). Information about the contribution of bushmeat to local livelihoods, actors in the supply chain, their motivations and their interpersonal relationships provides valuable context for designing hunting 
reduction programmes. Closer attention to social features in this system could reveal barriers and incentives for behaviour change that are often overlooked by conservationists. The role of bushmeat in people's livelihoods varies across sites; in many cases it provides a cheap source of protein as well as income (Foerster et al., 2012; Golden et al., 2014; SchulteHerbrüggen et al., 2013). The commercial supply chain typically involves multiple actors: traders or intermediaries who transport meat to markets, market-sellers, restaurateurs and consumers (Cowlishaw et al., 2005; Nielsen et al., 2016). Commercial hunting can be financially rewarding relative to local income alternatives (e.g. Coad et al., 2010; Nielsen and Meilby, 2015), and bushmeat may provide an economic safety net (Enuoh and Bisong, 2014), help to smooth income across lean seasons (Schulte-Herbrüggen et al., 2013), or generate social capital (De Merode et al., 2004; Van Vliet et al., 2015). The economic value of bushmeat presents a challenge of motivating behaviour change in individuals who have strong financial incentives to continue hunting, while ensuring that conservation efforts do not negatively impact vulnerable people (Roe, 2008).

Conservation strategies often aim to influence economic drivers of hunting. Regulatory interventions introduce financial risks such as fines for non-compliance with hunting restrictions (Tranquilli et al., 2014), while incentive-based approaches aim to alleviate economic dependence on wildlife resources (Niesten et al., 2010; Roe et al., 2015; Wright et al., 2016) or financially motivate behaviour change (Ferraro and Kiss, 2002). Projects often promote environmentally sustainable income sources (Roe et al., 2015), such as bee-keeping, while tools from social development, such as micro-credit schemes, are intended to improve social outcomes of conservation projects (Kaaya and Chapman, 2017). Aiming to change behaviour, cultural norms, and decision-making infrastructure, such interventions have the potential to alter social dynamics of local systems, which in turn may influence how natural resources are used (Miller et al., 2012). However, such feedback mechanisms are poorly understood (Larrosa et al., 2016), and there is little empirical guidance for conservation managers when it comes to designing interventions (Wicander and Coad, 2015).

The social context in which bushmeat hunting occurs may be central to developing effective conservation strategies. Social factors have a strong influence on behavioural decisions (Farrow et al., 2017; Morsello et al., 2015) and are inherent in bushmeat systems which typically involve multiple stakeholders. Yet components such as inter-personal relationships remain largely overlooked in conservation research (Robards et al., 2011). The handful of studies examining social features of bushmeat systems provide valuable insights (Coad et al., 2013; Cowlishaw et al., 2005; Nielsen et al., 2016; Nielsen and Meilby, 2015; Van Vliet et al., 2015, Van Vliet et al., 2014). For instance, Nielsen et al. (2016) describe an illegal 
bushmeat trading system built upon long-term relationships between hunters, traders and consumers, in which access to a trusted network created an entry barrier for hunting. The contrasting lack of inter-personal relationships with law-enforcers in this system may have contributed to violent rent-seeking behaviour. In the Amazon basin, Van Vliet et al. (2015) revealed substantial non-commercial flows of bushmeat to urban centres via close friendships and family ties, with sharing of meat linked to cultural identity and norms of reciprocity. Commercial trade meanwhile, was associated with a distinct socio-economic group who consumed meat as a luxury item. Framing bushmeat as a problem of common resource governance could also generate helpful insights (Smith et al., 2019) and adds prominence to factors such as trust and cooperation, which are often overlooked. Social environments can change rapidly in response to political, economic or technological shifts, which can have important consequences for resource use (Nackoney et al., 2014; Walters et al., 2015). A better understanding of the social context in which hunting systems operate provides a basis for designing appropriate conservation interventions and advances our understanding of behaviour change tools more generally.

Liberia is under-represented in the bushmeat literature (Taylor et al., 2015) despite high levels of bushmeat consumption and globally threatened wildlife populations. Anstey (1991) estimated that bushmeat provided $75 \%$ of the country's meat, generating \$24 million annually. A survey conducted after the civil conflict suggested that $80 \%$ of Monrovia's population consumed bushmeat, and found evidence that Liberia supplied a global trade with international exports from the capital (CEEB, 2004). More recently, a nationwide survey confirmed that hunting and consumption remains widespread (Junker et al., 2015b), although consumption decreased somewhat among wealthier households during the Ebola crisis in 2014-15 (Ordaz-Németh et al., 2017). This high level of demand coincides with an area of high conservation priority: Liberia retains the largest portion of forest in the Upper Guinea biodiversity hotspot (Mittermeier et al., 2003) and consequently harbours populations which are critical to the long-term survival of species such as western chimpanzee (Pan troglodytes verus) (Kühl et al., 2017) and pygmy hippopotamus (Choeropsis liberiensis) (Hillers et al., 2016). Over-hunting remains one of the principle threats for wildlife in Liberia and has resulted in local extirpation of large-bodied species (Junker et al., 2015a; Tweh et al., 2014). Financial incentives for hunters are likely to be high. The only existing study of hunters' incomes found average returns exceeded US $\$ 1500 /$ month for hunters in commercial camps near Sapo National Park (Greengrass, 2016). The economic role of bushmeat in rural livelihoods outside of professional hunting camps is largely undescribed and a better 
understanding of the economic and social structure of bushmeat systems in Liberia is needed to support conservation efforts in the region.

We aim to describe the structure of a bushmeat trading system in Liberia from a social, economic and livelihood perspective. We use a case-study from the Gola Forest to examine livelihood dependence, motivations and inter-personal relationships between hunters and traders.

\section{Methods}

\subsection{Study site}

The study was conducted in Kongba District, West Liberia, at the site of the Gola Management Agreement (GolaMA) conservation project (www.golarainforest.org/golaliberia). The area covers approximately $400 \mathrm{~km}^{2}$ of lowland rainforest, bordering Sierra Leone and connecting two protected areas that together form a transboundary "Peace Park", the Gola Forest National Park in Liberia, and the Gola Rainforest National Park in Sierra Leone. In Liberia, national laws prohibit hunting within protected areas and of certain species irrespective of where they are caught.

GolaMA is a community-based conservation management program that began in 2014, implemented by the Society for Conservation of Nature of Liberia and the Royal Society for the Protection of Birds. At the time of data collection, GolaMA's work focused on supporting communities to apply for legal forest management rights and introducing small-scale livelihood support projects such as agricultural training and bee-keeping initiatives. As in much of rural West Africa, subsistence agriculture forms a major component of local livelihood strategies, along with commercial crops including oil-palm and cocoa. The study area is also notable for diamond and gold deposits, and small-scale mining is a locally significant activity. The site has relatively low population density and high quality of forest resources (Hillers, 2013). Previous work shows hunting is practiced by about $40 \%$ of households, and hunters use shotguns (39\%), snares (24\%) or both (37\%) (Jones et al., 2009). A more detailed analysis of the demographic, livelihood and behavioural profiles of hunters in the site is presented by Jones et al. (2009).

Familiarity with the study site was obtained by SJ over a period of two years, and AF and ZN are local to the region. Data were collected by researchers who were local residents and where possible, female researchers conducted interviews with traders, many of whom were women. Interviews were conducted in English or local dialects based on respondents' preference. Preliminary results of a study using specialised techniques for asking sensitive 
questions (Lau et al., 2011; Nuno and St John, 2014) confirmed that hunters and traders were comfortable openly discussing hunting and bushmeat trading, and other potentially sensitive topics such as income sources (Jones et al., 2009). Ethical approval was given by Royal Holloway University of London Ethics Committee.

\subsection{Hunters}

Interviews were conducted between July 2016-July 2017 at all villages $(n=15)$ and two semi-permanent camps in the study site. Hunters were identified through meetings coordinated by chief hunters at each village, a household survey and snowball sampling. If hunters were not available for interview, researchers returned a minimum of three times before excluding them from the study. Hunters were asked general questions about their hunting activity and to provide details of their most recent hunting trip including species killed, the sale or consumption of carcasses, and prices received. To determine trade routes, hunters were asked the final destination of meat sold to traders. Hunters that could be refound were interviewed multiple times giving information for up to three separate hunting trips. Liberian dollars were converted to US\$ using the local exchange rate in July 2017 (LD100:US\$1). Catch was converted to raw biomass based on values in Kingdon, 2015 and Jones et al., 2009. Additional information relating to hunters' socio-demographic profiles were obtained during the hunter interviews and are presented in separate study (Jones et al., 2009).

The perceived contribution of hunting to personal income relative to other activities was assessed by inviting participants to share a pile of 20 beans among the income generating activities they had profited from in the past year. This was repeated for the past months' income share. Participants were also asked to estimate the income each activity generated over an average month and the previous year. Sample sizes are reported for questions about contribution of hunting to personal income that were added part way through the study.

\subsection{Traders}

Interviews were conducted with all traders identified in ten villages in the study site. We defined 'trader' as anyone who bought meat from one or more hunters and re-sold it. Five villages and two semi-permanent camps within the study site were not included due to their small size and inaccessibility (two camps), because no traders were identified or encountered (three villages) or due to time constraints (two villages). Traders were identified in the same way as hunters. Respondents were asked about trading behaviour and to provide details of 
their most recent transaction including species bought and sold. Contribution of trading to personal income was assessed with the bean-sharing method described above. Specific information regarding trade routes and customers was not requested as this could have led to targeted law enforcement efforts at road blocks. For this reason, we do not distinguish traders who acted as intermediaries by transporting meat for resale to market sellers or restaurateurs, from end-of-chain suppliers selling directly to consumers. However, it is our understanding that sales of meat transported to urban centres were typically made to market sellers, while local sales were to consumers.

\subsection{Focus group discussions}

Focus group discussions were conducted to generate broader understanding of hunting and trade by capturing personal perspectives of actors (Nyumba et al., 2018). One discussion per group was conducted with hunters in six villages and traders in one village. Groups comprised six to nine participants, recruitment was opportunistic based on availability of individuals encountered by the facilitator. Hunter discussions were mediated by a facilitator and recorded with a sound recorder. The trader focus group was restricted to female participants and mediated by a female facilitator with data recorded by a female note-taker. Topics discussed were: the challenges and benefits of bushmeat hunting or trade and the role of bushmeat in relation to other livelihood activities.

\section{Results}

\subsection{Socio-economic aspects of the hunting system}

\subsubsection{Hunters}

A total of 213 hunters were identified, of which 205 participated in the study. Of these, 48 hunters were interviewed on more than one occasion giving a sample of 253 hunting trips, totalling 999 hunting days. Hunter catch totalled 2088 carcasses from 30 species: 27 mammals, 2 birds and 1 reptile (Appendix A, Table A.1). Total harvested biomass was approximately 29 metric tonnes.

Hunters sold the majority of catch to traders (Fig. 1). Sales to traders for transport to urban markets included 24 species and accounted for most of the carcasses and harvested biomass. Local consumption included 23 species. Seven large and infrequently caught species were only recorded as sold to urban markets (Appendix A, Table A.1), including western chimpanzee (Pan troglodytes verus, $n=5$ ) and Jentink's duiker (Cephalophus jentinki, $n=9$ ). 
Six mainly small-bodied species were only consumed locally (Appendix A, Table A.1), including white-breasted guineafowl (Agelastes meleagrides, $n=16$ ) and greater cane-rat (Thryonomys swinderianus, $n=33$ ). Carcasses destined for urban markets were first dried by the hunters at the time of capture or by traders after purchase. Fresh carcasses were sold in local villages door-to-door by hunters and traders, either whole or butchered (pers. obs). Long journey times prevented transport of fresh carcasses to urban markets. The most common destination for meat was Liberia's capital, Monrovia, followed by markets in Sierra Leone and neighbouring Liberian counties. Hunters did not know the destination of $8 \%$ of carcasses ( $8 \%$ of biomass). Mean sale price reported by hunters was US\$ $0.82 \mathrm{~kg}^{-1}$ raw weight ( $\mathrm{SD}=0.37$, range $=0.05-2.78, n=765$ transactions) and did not vary substantially by species (Appendix B, Fig. B.1, Fig. B.2). Mean sale price of carcasses destined for urban consumers was slightly higher than local consumers (US $\$ 0.86 \mathrm{~kg}^{-1} \mathrm{SD}=0.38, n=495$, compared to US $\$ 0.74 \mathrm{~kg}^{-1}, \mathrm{SD}=0.31, n=270$ ). Mean price that traders reported paying hunters was slightly lower than the price hunters reported receiving from traders (US\$0.70 kg $\mathrm{SD}=0.18, n=114$ transactions, compared to US $\$ 0.83 \mathrm{~kg}^{-1}, \mathrm{SD}=0.37, n=622$

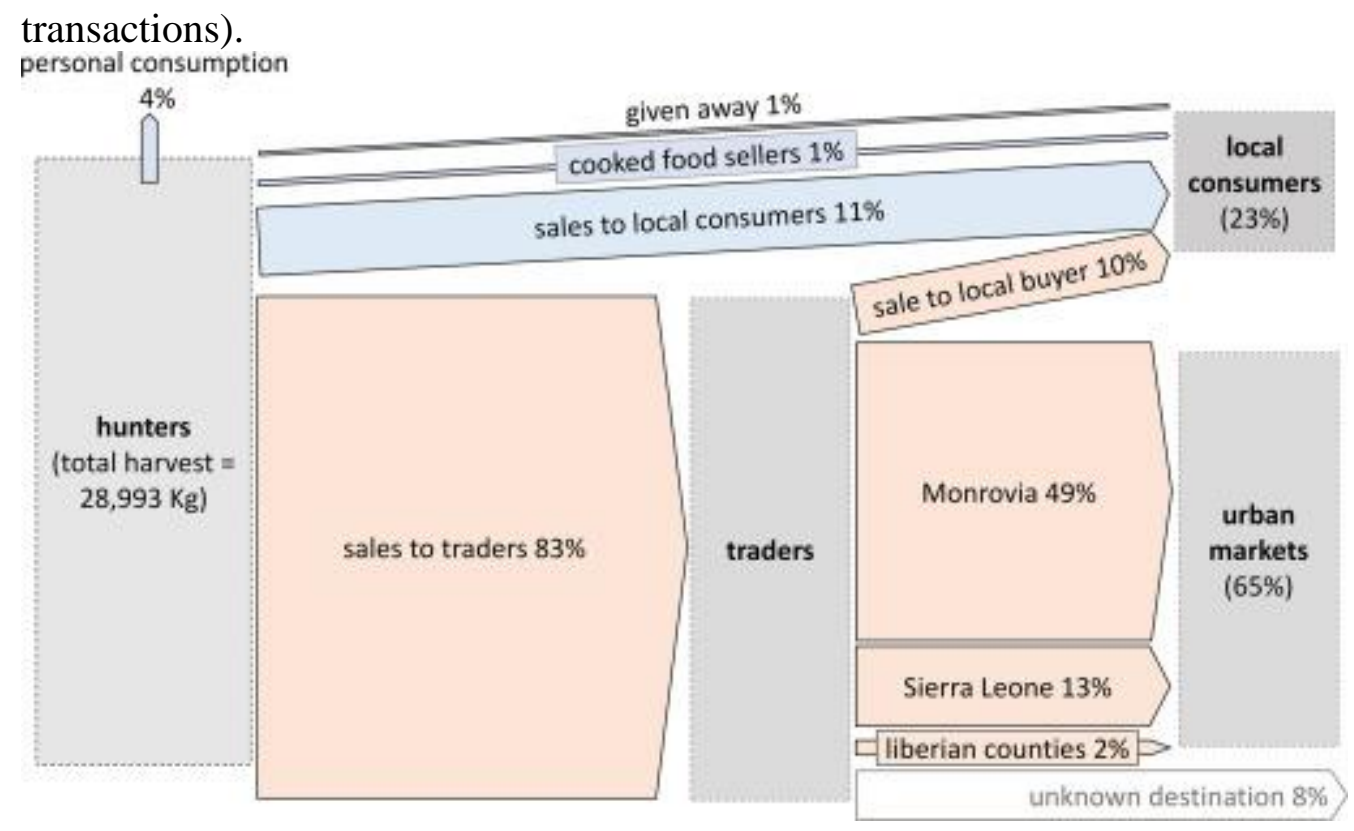

Fig. 1. Destination of wildlife harvest based on hunters' reports $(n=253$ hunting trips). All values shown are percentages of original total harvested biomass and width of arrows is proportional to volume in $\mathrm{kg}$.

Hunting was the principle income source for most hunters (74\%) followed by farming (19\%). Hunters estimated that bushmeat provided $62 \%$ of their income during the previous month on average (range $=5-100 \%$ ) and 55\% of income for the past year (range $=5-100 \%$; Fig. 2). Self-estimated monthly earnings from hunting ranged from $\$ 10-\$ 900$ (median $=120$, IQR $=80-200, n=174$; we exclude an unreasonably large estimate of \$2800). Hunters' 
average gross revenue per day during their most recent hunting trip was US\$22 (SD = 19,

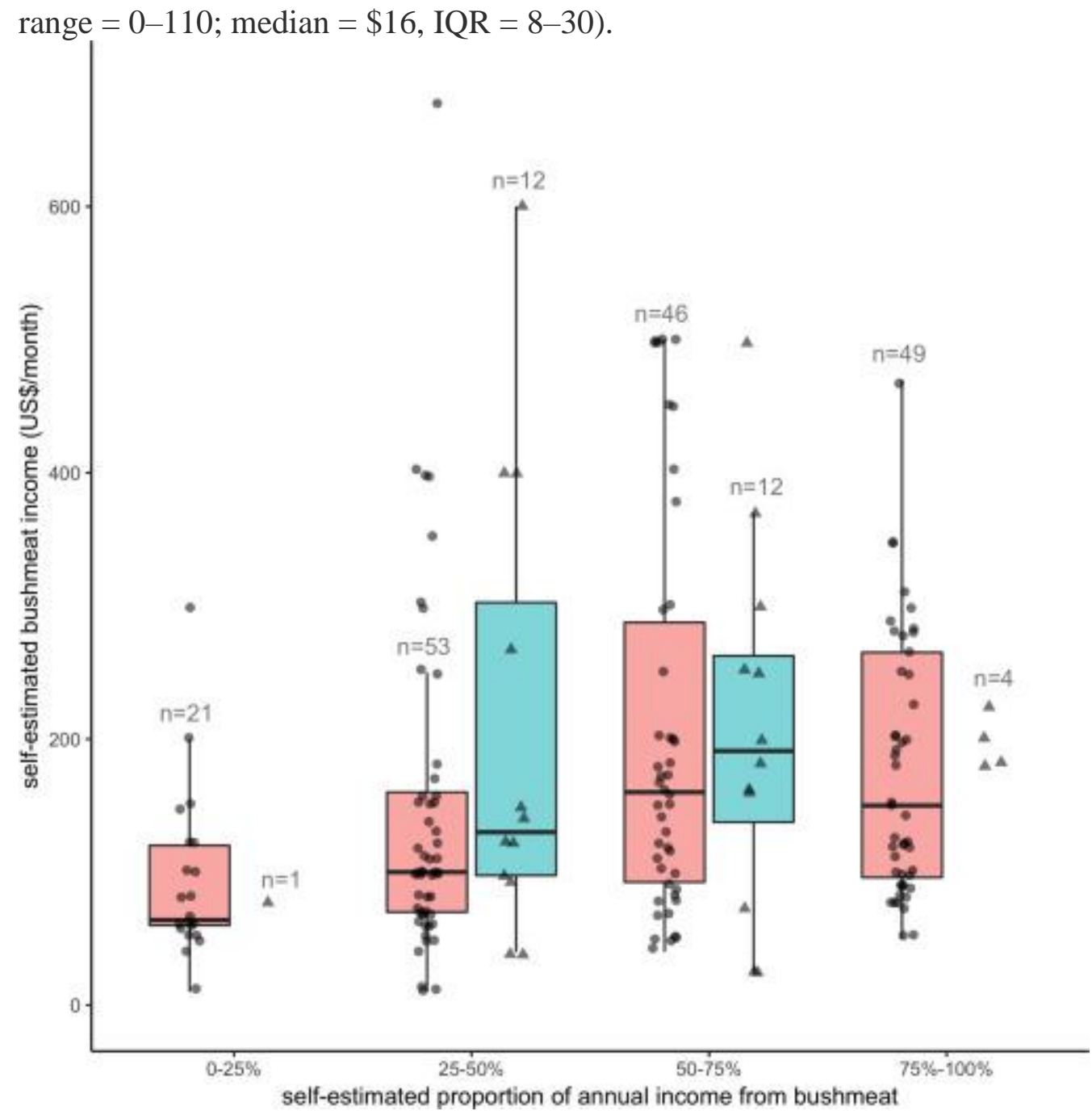

Fig. 2. Bushmeat income estimated by hunters (red, circles, $n=169$ ) and traders (blue, triangles, $n=29$ ), grouped according to perceived proportion of annual income from bushmeat. Four high hunter estimates are omitted for clarity, from income proportion categories 25-50\% (\$800/month), 50-75\% (\$800 and \$900/month) and $75-100 \%$ (\$2800/month). Boxes indicate median and 25\%-75\% quartile range for cases with at least 10 values, whiskers extend to $1.5 x \mathrm{IQR}$ beyond boxes. (For interpretation of the references to color in this figure legend, the reader is referred to the web version of this article.)

\subsubsection{Traders}

A total of 51 traders were identified and 50 participated in the study. Focus groups revealed that transient, non-resident traders operated in the area but were not identified during this study. We expect the trader sample therefore to represent only a portion of trading activity, with possible bias toward residents with a high social profile. Most (80\%) of traders were women and $38 \%$ came from the same village. The majority $(80 \%)$ had emigrated from 
elsewhere in Liberia between one and 25 years previously (median $=7, \mathrm{IQR}=3-12$ ). Among traders interviewed, $57 \%$ reported to sell at least some of their meat locally, $90 \%$ sold meat to Monrovia, $4 \%$ to Sierra Leone and $8 \%$ to the neighbouring Liberian county of Lofa. The majority (86\%) used cars to transport dried meat, and fees paid to commercial car operators ranged from US\$1.2-6.8 per carcass (mean $=\mathrm{US} \$ 3.8, \mathrm{SD}=1.5$ ).

Bushmeat trading was cited as the principle livelihood by the majority (78\%) of traders, followed by trading in other goods (14\%) such as foodstuffs, kitchenware or clothing. A majority of traders $(73 \%)$ also traded non-bushmeat goods. Traders estimated that bushmeat provided $53 \%$ of their income during the previous month on average (range $=0-100 \%$ ) and $49 \%$ of income for the past year (range $=20-100 \%$; Fig. 2). Self-estimated maximum monthly earnings ranged from US\$15-\$1600 (median $=200, \mathrm{IQR}=88-320)$ and minimum monthly earnings ranged from US\$10-\$1200 (median $=120$, IQR $=55-155)$. Estimates of typical monthly profits were from US $\$ 3-\$ 600$ (median $=120$, IQR $=59-220 ; n=42$, Fig. 2). Traders sold carcasses for an average of 1.9 times the price they paid hunters $(\mathrm{SD}=0.4$; range $=0.2-3.4)$. Mean re-sale prices reported by traders was US $\$ 1.30 \mathrm{~kg}^{-1}(\mathrm{SD}=0.54, n=119$ sales $)$. Traders often bought multiple carcasses over a period of time which were transported or sold together in a single 'transaction'. Traders conducted an average of 2.7 transactions per month $(\mathrm{SD}=2.1$, range $=0.5-15)$, selling an average of 17.9 carcasses per typical transaction $(S D=13.90$, range $=1-60)$. Mean expenses were US $\$ 86$ per transaction (median $=\$ 60$, range $=\$ 2-360$ ). Average net profit was US $\$ 87$ per transaction (median $=\$ 50$, range $=\$ 1-440, \mathrm{SD}=101.6$ ). However, a lower profit estimate of $\$ 24$ (range $=\$ 1-\$ 243$ ) was obtained when traders were asked to recall details of species bought and sold, rather than report their overall expenses and returns. Similarly, the mean number of carcasses recalled from the most recent transaction was substantially lower than the value reported as 'typical' (mean $=8.1, \mathrm{SD}=7.0$, range $=1-38$ ).

\subsection{Motivations and disincentives}

Confiscation of bushmeat by authorities was perceived as a considerable financial risk among both hunters and traders and was regularly mentioned in focus group discussions. Among hunters asked $(n=136), 45 \%$ had previously had meat confiscated at least once, and $25 \%$ had had their meat confiscated more than once. Median value of confiscated meat was US $\$ 390$ (range $=\mathrm{US} \$ 50$ to $2500, \mathrm{IQR}=225-642, n=58$ ). Among traders, $71 \%$ had had their meat confiscated at least once, and $58 \%$ on more than one occasion. Median value of confiscated meat was $\$ 320$ (range $=$ US $\$ 22$ to $1804, n=36)$. 
The majority of hunters and traders reported doing less hunting or trade in the previous year than the preceding one ( $70 \%$ of hunters, $90 \%$ of traders; Table 1 ). The most common reason given by hunters was involvement in other activities such as farming, followed by enforcement of government restrictions and fewer animals. Most traders cited government restrictions, followed by reduction in animal populations (Table 1). Traders asked about factors that made meat trade challenging most frequently cited confiscation of meat at roadblocks (31 respondents, 62\%; Appendix C, Table C.1), followed by the costs of transportation (6 respondents, 12\%) and issues relating to mistrust with hunters such as paying hunters in advance without receiving meat in return (6 respondents, $12 \%$ ).

Table 1. Reasons given by hunters $(n=92)$ and traders $(n=45)$ who stated during interviews they had reduced their effort in bushmeat activities in the previous year compared to the preceding one. Values are the percentage and number of total respondents giving each reason.

\section{Reasons for reduction in hunting/trading effort in the previous year Hunters Traders (example statements)}

Government restrictions and law enforcement

"the arresting of meat on the road"

$21 \% \quad 60 \%$

"because they're taking the meat from us"

Replacement with a different income generating activity

"farming is now my focus point"

"because I went to gold mining"

"busy with farming"

"I have more activities this year than hunting"

Fewer animals

"the animals are not as many compared to last year"

"I travel far distance in hunting and get less animals"

Awareness about conservation, GolaMA project activities

"conservation message"

"golama say no hunting"

Personal/health issues

Financial barriers, lack of gun

"bullets are expensive"

"someone go with my gun"

Limited by supply from hunters, or support from traders

"more hunters leaving their hunting tent"

"because the hunters are not doing any hunting"

"I did more hunting [before] because of my partner help"

Transportation issues

"poor road condition"

Trader focus group discussion indicated transportation costs were a key factor perceived to limit bushmeat profitability and that these were exacerbated both by poorly maintained roads 
and a local monopoly of commercial vehicle operators. Participants noted that transportation barriers were reduced when companies (such as logging or mining companies) were active in the area. However, high costs of transporting goods simultaneously created a motivation for increased involvement in bushmeat trade. This was because traders taking bushmeat to urban centres had the opportunity to purchase goods with cash from bushmeat sales. Profit margins for non-bushmeat goods were reportedly low and more severely impacted by transport prices, motivating traders to compensate by increasing bushmeat sales to make up the shortfall. Purchase of goods and gun cartridges in urban markets using cash from bushmeat sales may have helped offset the cost of return journeys. Traders also minimised transport fares by sending meat via trusted third parties, such as vehicle operators, to known urban buyers without travelling themselves. Traders rarely transported non-bushmeat goods, such as nontimber forest products or agricultural produce, to urban centres due prohibitively expensive fares.

\subsection{Hunter trader relations}

Partnerships between hunters and traders were frequently mentioned during focus group discussions, and $28 \%$ of hunters had a specific "business partner". Two thirds of partnerships were with female traders, and $13 \%$ were with spouses or family members. Mean duration of partnerships was 2.7 years ( $\mathrm{SD}=3.4, n=39$ ). Typically, trading partners offered hunters financial support of some kind, to be repaid with a regular supply of meat. In $68 \%$ of such arrangements, trading partners provided gun cartridges, but exchanges also included food $(42 \%)$, cash advances $(11 \%)$, wire for snares $(8 \%)$ or other items such as batteries $(5 \%)$. The most frequent agreement was that hunters provide the equivalent of two medium-sized duiker carcasses (totalling 30-40 kg in raw weight) in exchange for a box of 25 gun cartridges (39\% of agreements). Other common arrangements were that hunters provide the trader with a minimum number of carcasses per month ( $31 \%$ of agreements), or that hunters agree to exclusively sell their catch to the partner (8\%). Agreements were similar for partnerships with male or female traders. Informal discussions indicated that relationships between hunters and traders were complex and varied. For instance, traders who owned small businesses offered hunters credit for goods such as food, cigarettes and alcohol, to be repaid with meat from their next hunting trip. Reports suggested some hunters followed a predictable pattern of generating debt in the village, followed by hunting trips to repay creditors - a cycle which made it hard to generate capital to pursue alternative income sources. Traders who were not local residents were reported to travel into the study site from urban centres with goods such as clothing to exchange for meat from hunters. A popular narrative was of hunters cheating 
traders who provided gun cartridges and food for hunting trips, by secretly selling meat in the forest and claiming not to have caught anything. Romantic relationships between hunters and traders of different gender were also alluded to as somewhat common. It was noted that hunters were able to help girlfriends or wives by providing them with bushmeat to sell, as well as off-cuts to eat and direct financial support. Informal conversations with hunters, traders and other local citizens suggested that a majority of traders selling meat in Monrovia had close ties with a single trusted buyer. This buyer could be relied upon to safeguard traders' money until it was needed, much like a bank or savings group, and offered credit or financial support in times of crisis to both hunters and traders. Taken together, such anecdotes implied that interpersonal relationships were important components of the hunting-trading system.

\section{Discussion}

This study provides the first detailed description of the social and economic structure of a rural Liberian bushmeat system. The results reveal substantial livelihood dependence on bushmeat with high financial incentives for both hunters and traders. Bushmeat demand came from both local and urban markets with a high proportion of meat destined for Monrovia. Hunters and traders each had different motivations to reduce effort, suggesting that conservation programmes need to operate across multiple groups in order to be effective. Such programmes also need to take into account the complex social contexts within which hunting and trade operate. We found evidence that inter-personal relationships between hunters and traders, characterised by credit arrangements based on mutual trust, were influential components of the system, yet these are often overlooked.

We found bushmeat was a significant cash-generating component of local livelihoods: more than half of hunters and traders estimated that bushmeat provided at least $50 \%$ of annual income, and almost three quarters of hunters considered hunting their principle profession. This reinforces the need for livelihood support tools to be integrated into conservation strategies. Financial incentives of individuals were also considerable. Typical earnings of hunters and traders were variable and generally high relative to local opportunities; a pattern that has been observed at other sites across Africa (Coad et al., 2010; Grande-Vega et al., 2013; Olupot and Plumptre, 2009). Hunters reported earning \$120/month, whereas monthly earnings for local teachers range from $\$ 40-\$ 100$, unskilled company employees (e.g. security guards) receive $\$ 70-\$ 80$, and small-holder cocoa farmers can generate approximately $\$ 300 /$ year on 3 ha (S. Kamara, personal communication). Standard rates for manual labour 
are \$5/day (pers. obs) while hunters were able to earn \$10-\$20/day. Traders' incomes were slightly higher, with average self-estimated monthly earnings between $\$ 120-\$ 260$. Selfreported incomes should be interpreted cautiously since they are prone to error and reporting bias (Krumpal, 2013; Mathiowetz et al., 2002). Nevertheless, values from this study fall within the range recorded for similar settings (e.g. Coad et al., 2010; Kümpel et al., 2009; De Merode et al., 2004; Grande-Vega et al., 2013) and provide a benchmark to inform conservation efforts.

Bushmeat incomes were an order of magnitude lower than those previously recorded by Greengrass (2016) at commercial camps near Liberia's Sapo National Park. This is unsurprising as our study describes a village hunting system, rather than a camp of professional hunters. However, the upper range of estimates in our study exceeded $\$ 1000 /$ month, suggesting that even in a village context, a minority of hunters may have considerable financial incentives. Effective conservation may depend on clearly identifying and defining target groups for behaviour change interventions (Jones et al., 2009). In Gola, a small number of 'high-impact' hunters likely capture a disproportionate share of harvest and profit - a pattern that is commonly reported (e.g. Abernethy and Ndong Obiang, 2010; Luz et al., 2017). In such systems, altering behaviour of a majority of hunters may have less impact than influencing the group of highest earning individuals using a more targeted approach. Hunters and traders gave different reasons for reducing effort in bushmeat trade. Traders most frequently cited the risk of financial losses due to checkpoint confiscations, whereas most hunters cited increased involvement in activities such as farming. Checkpoints operate across Liberia and are relatively cheap to maintain. We found meat confiscation generated substantial financial risks, particularly for traders, many of whom had lost assets reaching hundreds of dollars. Most traders cited confiscation of meat alongside transportation costs as a major barrier to generating income from trade. While confiscation risk may act as a deterrent, it was insufficient to motivate hunters or traders to completely abandon their activities. A principle reason given for this was lack of alternative, equivalent, income sources. In contrast to traders, hunters most frequently cited doing other activities as a reason for reduced hunting effort. This implies that promotion of non-hunting activities which are time-demanding, but profitable, could be a successful conservation tool. As with the traders' responses, stated motivations do not constitute evidence of genuine behaviour change, and should be interpreted as factors which are perceived to influence choices. Nevertheless, the difference between hunters' and traders' responses provides useful hypotheses that could be formally tested: that traders are influenced by interventions to increase financial risks, while hunters respond best to increased demands on their time from alternative activities. 
Our case-study demonstrates the need to consider the wider social context of hunting in order to obtain an accurate picture of bushmeat systems. For instance, the use of cash from bushmeat sales to boost other income sources merits further attention since this implies that simple models may not capture the true economic contribution of bushmeat. Nearly a third of hunters in this study maintained specific business partnerships with traders, and credit arrangements between the two groups were varied and complex. This underlying structure has implications for the design of interventions such as small loans schemes which are likely to influence hunter-trader relations. Trust and cooperation between actors may also be influential. Untrustworthiness of hunters was seen by traders as a significant barrier for generating profit, while a small number of hunters mentioned break-down of trading partnerships as motivation for decreasing their hunting effort. The nature of hunter-trader relationships may be revealing and could be influenced by conservation actions. For instance, Nielsen et al. (2016) report a system in Tanzania in which hunters advanced credit to traders - the reverse of what was observed in our study. This difference may be linked to differences in the risk and profit experienced by hunters and traders, with the implication that hunter-trader dynamics may be sensitive to interventions such as law enforcement. Trust can promote sustainable management of resources such as bushmeat by facilitating cooperative behaviour (Bouma et al., 2017; Vollan et al., 2013). However, our results imply that higher trust and cooperation in hunter and trader partnerships may promote over-hunting by minimising the financial risks and uncertainty faced by both parties. More generally, one-toone relationships could make hunting systems more resistant to interventions by creating social expectations and obligations. A clearer understanding of social dynamics in bushmeat systems, and the way these are affected by conservation actions, could improve the design of interventions.

\section{Conclusions}

Bushmeat hunting in Liberia has received little research attention but is a major threat for endangered species in the region (Greengrass, 2016; Taylor et al., 2015). Our case-study illustrates the challenge of sustainable management of bushmeat resources in the face of large financial incentives and high livelihood dependence on wildlife. We found that motivations differed between hunters and traders, suggesting a promising direction for future work lies in determining whether livelihood support and law enforcement may be more effectively targeted. Social structures and processes such as interpersonal trust, were seen to be influential and merit closer attention in bushmeat research. 


\section{Acknowledgements}

Funding for this research was provided by the Royal Society for the Protection of Birds and the European Union through the project "Securing Liberian forest connectivity through Community Forestry and Innovative Financing". The funding source had no involvement in study design, data collection or interpretation of results. We thank the Forestry Development Authority of Liberia, the Clan Authorities and community leaders for permission to conduct this work. We further thank the Society for the Conservation of Nature of Liberia and GolaMA staff, with special thanks to M. Garbo and A. Gardner. We also thank two anonymous reviewers for their helpful comments.

\section{Appendix A}

Table A.1. Species harvested by 208 hunters over 999 hunting days in the Gola Forest, based on recall from most recent hunting trip. Ordered by percentage of total biomass.

\begin{tabular}{|c|c|c|c|c|c|c|}
\hline Species & $\begin{array}{l}\text { Species } \\
\text { group }\end{array}$ & $\begin{array}{c}\text { number of } \\
\text { carcasses }\end{array}$ & $\begin{array}{c}\text { total } \\
\text { biomass } \\
(\mathrm{kg})\end{array}$ & $\begin{array}{l}\text { percent of } \\
\text { all } \\
\text { carcasses }\end{array}$ & $\begin{array}{c}\text { percent of } \\
\text { total } \\
\text { biomass }\end{array}$ & $\begin{array}{l}\text { destination of } \\
\text { carcasses }\end{array}$ \\
\hline $\begin{array}{l}\text { Cephalophus } \\
\text { dorsalis }\end{array}$ & $\begin{array}{l}\text { Medium } \\
\text { ungulate }\end{array}$ & 500 & $10,000.0$ & 23.1 & 27.7 & Urban + local \\
\hline $\begin{array}{l}\text { Philantomba } \\
\text { maxwellii }\end{array}$ & $\begin{array}{c}\text { Small } \\
\text { ungulate }\end{array}$ & 811 & 6940.3 & 37.4 & 19.2 & Urban + local \\
\hline $\begin{array}{l}\text { Syncerus caffer } \\
\text { nanus }\end{array}$ & $\begin{array}{l}\text { Large } \\
\text { ungulate }\end{array}$ & 11 & 6519.3 & 0.5 & 18.0 & Urban + local \\
\hline $\begin{array}{l}\text { Potamochoerus } \\
\text { porcus }\end{array}$ & $\begin{array}{c}\text { Large } \\
\text { ungulate }\end{array}$ & 49 & 3430.0 & 2.3 & 9.5 & Urban + local \\
\hline $\begin{array}{l}\text { Cephalophus } \\
\text { niger }\end{array}$ & $\begin{array}{l}\text { Medium } \\
\text { ungulate }\end{array}$ & 117 & 2234.0 & 5.4 & 6.2 & Urban + local \\
\hline $\begin{array}{l}\text { Hylochoerus } \\
\text { meinertzhageni }\end{array}$ & $\begin{array}{c}\text { Large } \\
\text { ungulate }\end{array}$ & 4 & 792.5 & 0.2 & 2.2 & Urban + local \\
\hline Cercocebus atys & Primate & 114 & 791.3 & 5.3 & 2.2 & Urban + local \\
\hline $\begin{array}{l}\text { Tragelaphus } \\
\text { scriptus }\end{array}$ & $\begin{array}{l}\text { Medium } \\
\text { ungulate }\end{array}$ & 17 & 735.3 & 0.8 & 2.0 & Urban + local \\
\hline $\begin{array}{l}\text { Cephalophus } \\
\text { jentinki }\end{array}$ & $\begin{array}{c}\text { Large } \\
\text { ungulate }\end{array}$ & 9 & 616.4 & 0.4 & 1.7 & Urban \\
\hline $\begin{array}{l}\text { Tragelaphus } \\
\text { eurycerus }\end{array}$ & $\begin{array}{c}\text { Large } \\
\text { ungulate }\end{array}$ & 2 & 542.0 & 0.1 & 1.5 & Urban \\
\hline $\begin{array}{l}\text { Colobus } \\
\text { polykomos }\end{array}$ & Primate & 59 & 519.0 & 2.7 & 1.4 & Urban + local \\
\hline $\begin{array}{l}\text { Hyemoschus } \\
\text { aquaticus }\end{array}$ & $\begin{array}{l}\text { Medium } \\
\text { ungulate }\end{array}$ & 46 & 499.1 & 2.1 & 1.4 & Urban + local \\
\hline
\end{tabular}




\begin{tabular}{|c|c|c|c|c|c|c|}
\hline Species & $\begin{array}{l}\text { Species } \\
\text { group }\end{array}$ & $\begin{array}{l}\text { number of } \\
\text { carcasses }\end{array}$ & $\begin{array}{c}\text { total } \\
\text { biomass } \\
(\mathbf{k g})\end{array}$ & $\begin{array}{l}\text { percent of } \\
\text { all } \\
\text { carcasses }\end{array}$ & $\begin{array}{c}\text { percent of } \\
\text { total } \\
\text { biomass }\end{array}$ & $\begin{array}{l}\text { destination of } \\
\text { carcasses }\end{array}$ \\
\hline $\begin{array}{l}\text { Choeropsis } \\
\text { liberiensis }\end{array}$ & $\begin{array}{l}\text { Large } \\
\text { ungulate }\end{array}$ & 2 & 470.0 & 0.1 & 1.3 & Urban \\
\hline $\begin{array}{l}\text { Atherurus } \\
\text { africanus }\end{array}$ & Rodent & 108 & 310.6 & 5.0 & 0.9 & Urban + local \\
\hline $\begin{array}{l}\text { Monkey - } \\
\text { undefined species }\end{array}$ & Primate & 51 & $296.6^{\mathrm{a}}$ & 2.4 & 0.8 & Urban + local \\
\hline $\begin{array}{l}\text { Cercopithecus } \\
\text { diana }\end{array}$ & Primate & 59 & 257.2 & 2.7 & 0.7 & Urban + local \\
\hline $\begin{array}{l}\text { Cercopithecus } \\
\text { petaurista }\end{array}$ & Primate & 70 & 226.4 & 3.2 & 0.6 & Urban + local \\
\hline $\begin{array}{l}\text { Pan troglodytes } \\
\text { verus }\end{array}$ & Primate & 5 & 225.0 & 0.2 & 0.6 & Urban \\
\hline $\begin{array}{l}\text { Piliocolobus } \\
\text { badius }\end{array}$ & Primate & 25 & 210.8 & 1.2 & 0.6 & Urban + local \\
\hline $\begin{array}{l}\text { Thryonomys } \\
\text { swinderianus }\end{array}$ & Rodent & 33 & 123.8 & 1.5 & 0.3 & Local \\
\hline $\begin{array}{l}\text { Cercopithecus } \\
\text { campbelli }\end{array}$ & Primate & 32 & 116.1 & 1.5 & 0.3 & Urban + local \\
\hline Panthera pardus & Carnivore & 2 & 104.8 & 0.1 & 0.3 & Urban \\
\hline $\begin{array}{l}\text { Cephalophus } \\
\text { silvicultor }\end{array}$ & $\begin{array}{l}\text { Large } \\
\text { ungulate }\end{array}$ & 1 & 62.0 & 0.0 & 0.2 & Urban \\
\hline $\begin{array}{l}\text { Cephalophus } \\
\text { ogilbyi ssp } \\
\text { brookei }\end{array}$ & $\begin{array}{l}\text { Medium } \\
\text { ungulate }\end{array}$ & 2 & 36.8 & 0.1 & 0.1 & Urban \\
\hline Crocodile ${ }^{\underline{b}}$ & Reptile & 1 & $25.0^{\mathrm{a}}$ & 0.0 & 0.1 & Local \\
\hline $\begin{array}{l}\text { Nandinia } \\
\text { binotata }\end{array}$ & Carnivore & 9 & 19.5 & 0.4 & 0.1 & Urban + local \\
\hline $\begin{array}{l}\text { Mongoose - } \\
\text { undefined species }\end{array}$ & Carnivore & 11 & $15.3^{\mathrm{a}}$ & 0.5 & $<0.1$ & Local \\
\hline $\begin{array}{l}\text { Agelastes } \\
\text { meleagrides }\end{array}$ & Bird & 16 & 13.0 & 0.7 & $<0.1$ & Local \\
\hline $\begin{array}{l}\text { Large raptor or } \\
\text { Palm-nut vulture }\end{array}$ & Bird & 2 & $7.2^{\mathrm{a}}$ & 0.1 & $<0.1$ & Local \\
\hline Manis tricuspis & Pangolin & 1 & 1.5 & $<0.1$ & $<0.1$ & Local \\
\hline
\end{tabular}

$\mathrm{a}$

For undefined species, body mass of the most commonly killed member of the species group were used based on information provided by hunters. For monkeys the mean adult body mass of all monkey species was used. 
b

Osteolaemus tetraspis or Mecistops cataphractus.

\section{Appendix B}

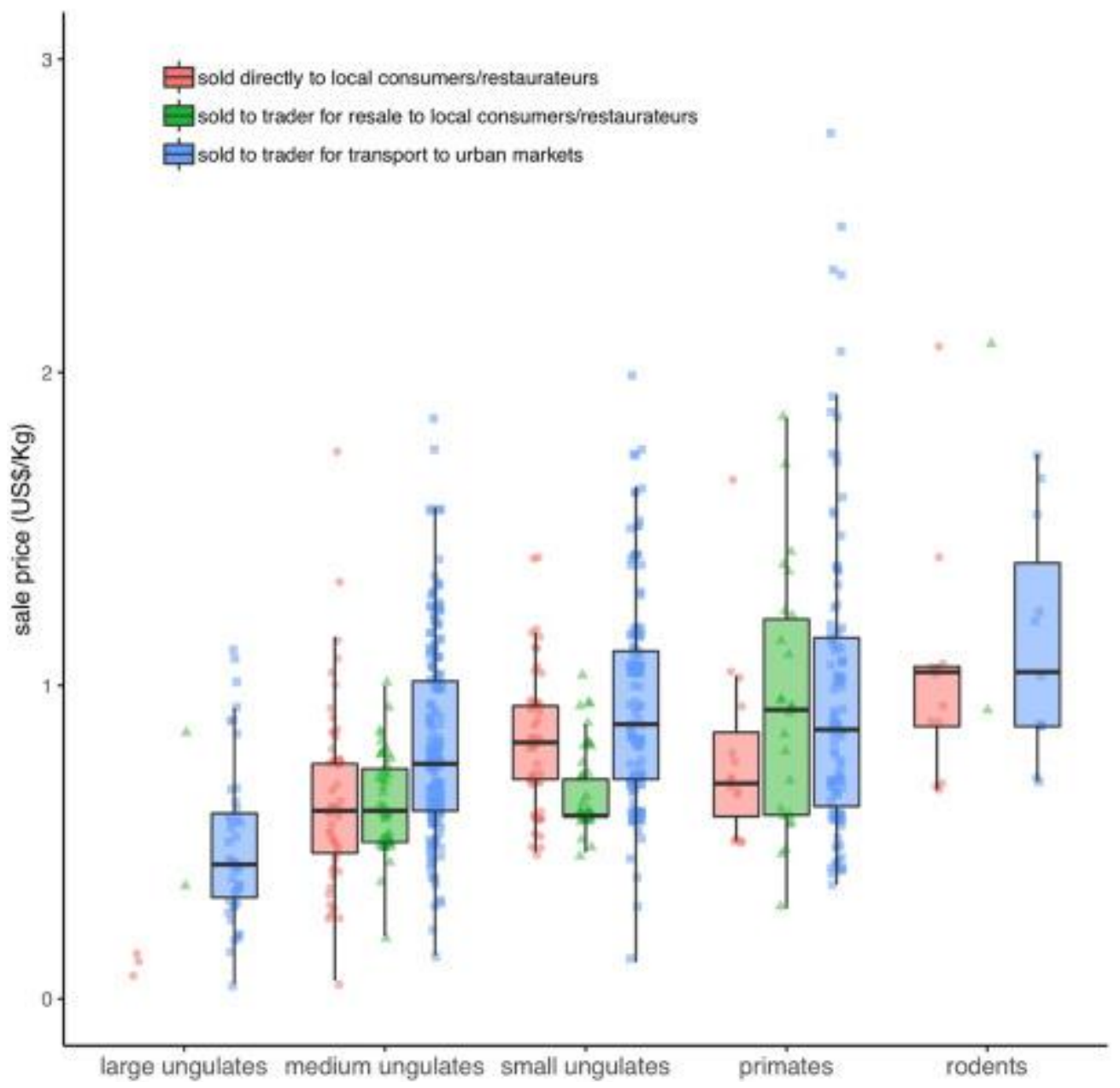

1. Download high-res image (144KB)

2. Download full-size image

Fig. B.1. Prices received by hunters from bushmeat sold directly to local consumers or restaurateurs (red, circles), to traders intending to sell the meat to local consumers or restaurateurs (green, triangles), and to traders for transport to urban centres (blue, squares). Points show values of individual transactions $(n=759)$. Boxes indicate median and 25\%-75\% quartile range for cases with at least ten transactions, whiskers extend to $1.5 \mathrm{xIQR}$ beyond boxes. (For interpretation of the references to color in this figure legend, the reader is referred to the web version of this article.) 


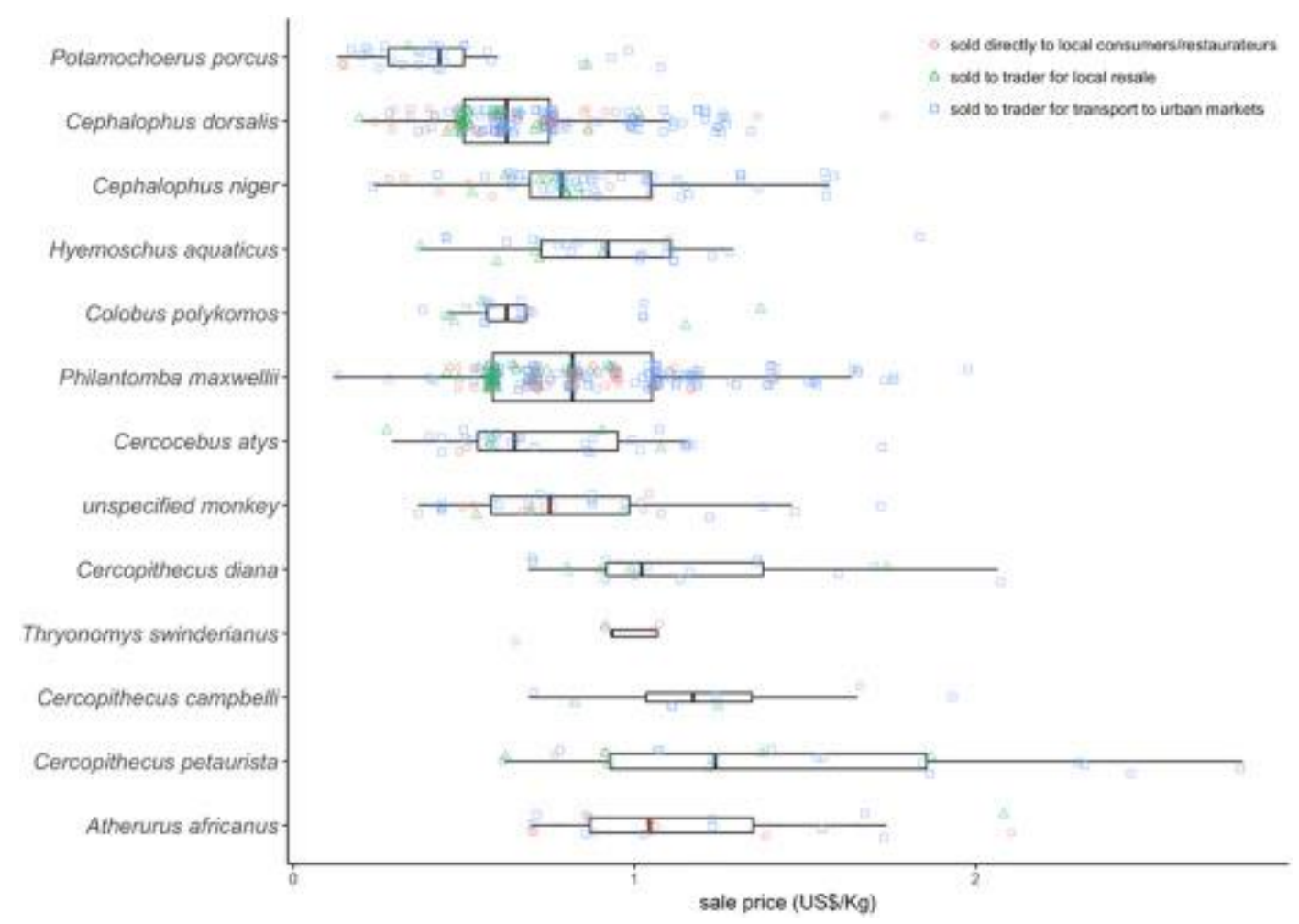

Fig. B.2. Sale prices received by hunters for the most frequently killed species, in order of body size. Points indicate hunters' sales directly to local consumers or restaurateurs (red circles), sales to traders for local resale (green triangles), or sales to traders for transport to urban markets (blue squares). Median and 25\%-75\% quartiles range are indicated by boxes, widths are proportional to the number of carcasses sold. Species are ordered by mean body size (smallest at the bottom). (For interpretation of the references to color in this figure legend, the reader is referred to the web version of this article.)

\section{Appendix C}

Table C.1. Factors considered by traders to be the principle challenges of bushmeat trading, data from interviews with 50 traders.

\section{Principle challenges for bushmeat traders (example statements)}

\section{Percentage of respondents}

Government restrictions and law enforcement

"FDA [Forestry Development Authority of Liberia] law"

"the arresting of meat on the road"

Trustworthiness of hunters

"you paid the hunters for the meat and you don't get it sometime"

"some hunters will carry your money and don't come back"

"we have to go after some of the hunter to get [our] goods"

"to get dry meat from the hunter is not easy"

Poor road condition

"bad road condition and huge transportation fare"

"accessibility, poor road conditions" 
Travelling long distances

"moving from one place to another to get meat"

"walking from place to another"

"going on far distance to get the meat, sometime you don't see the

hunter"

Conservation

"Due to conservation"

Declining wildlife abundance

"shortage of animals"

Other - personal

\section{References}

K.A. Abernethy, A.M. Ndong ObiangBushmeat in Gabon. Libreville, Gabon:

Technical Report

Ministère des Eaux et Forets (2010), 10.13140/RG.2.2.28730.18881

S. AnsteyWildlife Utilization in Liberia: The Findings of a National Survey 19891990

(1991)

(Report to WWF/FDA)

A. Benítez-

López, R. Alkemade, A.M. Schipper, D.J. Ingram, P.A. Verweij, J.A.J. Eikelboom, M .A.J. HuijbregtsThe impact of hunting on tropical mammal and bird populations Science (80-.), 356 (2017), pp. 180-183

https://doi.org/10.1126/science.aaj1891

J. Bouma, V. Reyes-García, T. Huanca, S. ArrazolaUnderstanding conditions for co-management: a framed field experiment amongst the Tsimane', Bolivia Ecol. Econ., 141 (2017), pp. 32-42

https://doi.org/10.1016/j.ecolecon.2017.05.013

D.M. Cawthorn, L.C. HoffmanThe bushmeat and food security nexus: a global account of the contributions, conundrums and ethical collisions

Food Res. Int., 76 (2015), pp. 906-925

https://doi.org/10.1016/j.foodres.2015.03.025

CEEBMonrovia Liberia as the transport hub for the bushmeat trade

Concerned Environmentalists for the Enhancement of Biodiversity, Monrovia, Liberia and Conservation International, Washington DC, USA (2004)

L. Coad, K. Abernethy, A. Balmford, A. Manica, L. Airey, E.J. Milner-

GullandDistribution and use of income from bushmeat in a rural village, Central

Gabon

Conserv. Biol., 24 (2010), pp. 1510-1518

https://doi.org/10.1111/j.1523-1739.2010.01525.x 
L. Coad, J. Schleicher, E.J. Milner-

Gulland, T.R. Marthews, M. Starkey, A. Manica, A. Balmford, W. Mbombe, T.R. Dio p Bineni, K.A. AbernethySocial and ecological change over a decade in a village hunting system, Central Gabon

Conserv. Biol., 27 (2013), pp. 270-280

https://doi.org/10.1111/cobi.12012

G. Cowlishaw, S. Mendelson, J.M. RowcliffeStructure and operation of a bushmeat commodity chain in Southwestern Ghana

Conserv. Biol., 19 (2005), pp. 139-149

https://doi.org/10.1111/j.1523-1739.2005.00170.x

E. De Merode, K. Homewood, G. CowlishawThe value of bushmeat and other wild foods to rural households living in extreme poverty in Democratic Republic of Congo

Biol. Conserv., 118 (2004), pp. 573-581

https://doi.org/10.1016/j.biocon.2003.10.005

A.R. DorwardLivelisystems: a conceptual framework integrating social, ecosystem, development, and evolutionary theory

Ecol. Soc., 19 (2014)

https://doi.org/10.5751/ES-06494-190244

O.O.O. Enuoh, F.E. BisongRural Livelihoods Vulnerabilities and Commercial

Bushmeat Hunting Challenges in Cross River National Park, Nigeria

(2014), pp. 822-836

https://doi.org/10.4236/nr.2014.513071

K. Farrow, G. Grolleau, L. IbanezSocial norms and pro-environmental behavior: a review of the evidence

Ecol. Econ., 140 (2017), pp. 1-13

https://doi.org/10.1016/j.ecolecon.2017.04.017

P.J. Ferraro, A. KissDirect payments to conserve biodiversity

Science (80-.), 298 (2002), pp. 1718-1719

https://doi.org/10.1126/science.1078104

S. Foerster, D.S. Wilkie, G.A. Morelli, J. Demmer, M. Starkey, P. Telfer, M. Steil, A. LewbelCorrelates of bushmeat hunting among remote rural households in

Gabon, Central Africa

Conserv. Biol., 26 (2012), pp. 335-344

https://doi.org/10.1111/j.1523-1739.2011.01802.x

C.D. Golden, M.H. Bonds, J.S. Brashares, R.B.J. Rasolofoniaina, C. KremenEconomi c valuation of subsistence harvest of wildlife in Madagascar

Conserv. Biol., 28 (2014), pp. 234-243

https://doi.org/10.1111/cobi.12174 
M. Grande-Vega, B. Carpinetti, J. Duarte, J.E. FaContrasts in Livelihoods and Protein Intake between Commercial and Subsistence Bushmeat Hunters in Two Villages on Bioko Island, Equatorial Guinea

Conserv. Biol., 27 (2013), pp. 576-587, 10.1111/cobi.12067

E. Greengrass Commercial hunting to supply urban markets threatens mammalian biodiversity in Sapo National Park, Liberia

Oryx, 50 (2016), pp. 397-404

https://doi.org/10.1017/S0030605315000095

A. HillersAcross the River - A transboundary Peace Park for Sierra Leone and Liberia: Final report on the activities of the research unit Royal Society for the Protection of Birds, U.K. (2013)

A. Hillers, G.M. Buchanan, J.C. Garteh, S.M. Tommy, M.L. Fofana, J.a. LindsellA mix of community-based conservation and protected forests is needed for the survival of the Endangered pygmy hippopotamus Choeropsis liberiensis Oryx (2016), pp. 1-10 https://doi.org/10.1017/S003060531600020X

K.E. Jones, J. Bielby, M. Cardillo, S.A. Fritz, J. O’Dell, D.L. Orme, S. Kamran, W. S echrest, E.H. Boakes, C. Carbone, C. Connolly, M.J. Cutts, J.K. Foster, R. Grenyer, M. Habib, C.A. Plaster, S.A. Price, E.A. Rigby, J. Rist, A. Teacher, O.R.P. BinindaEmonds, J.L. Gittleman, G.M. Mace, A. PurvisPanTHERIA: a species-level database of life history, ecology, and geography of extant and recently extinct mammals

Ecology, 90 (2009), p. 2648

J. Junker, C. Boesch, T. Freeman, R. Mundry, C. Stephens, H.S. KühlIntegrating wildlife conservation with conflicting economic land-use goals in a West African biodiversity hotspot

Basic Appl. Ecol., 16 (2015), pp. 690-702

https://doi.org/10.1016/j.baae.2015.07.002

J. Junker, C. Boesch, R. Mundry, C. Stephens, M. Lormie, C. Tweh, H.S. KühlEduca tion and access to fish but not economic development predict chimpanzee and mammal occurrence in West Africa

Biol. Conserv., 182 (2015), pp. 27-35

https://doi.org/10.1016/j.biocon.2014.11.034

E. Kaaya, M. ChapmanMicro-credit and community wildlife management: complementary strategies to improve conservation outcomes in Serengeti National Park, Tanzania

Environ. Manage., 60 (2017), pp. 464-475

https://doi.org/10.1007/s00267-017-0856-x

J. KingdonThe Kingdon field guide to African mammals 2nd edition Bloomsbury Publishing, London, UK (2015)

I. KrumpalDeterminants of social desirability bias in sensitive surveys: a literature review 
Qual. Quant., 47 (2013), pp. 2025-2047

https://doi.org/10.1007/s11135-011-9640-9

H.S. Kühl, T. Sop, E.A. Williamson, R. Mundry, D. Brugière, G. Campbell, H. Cohen , E. Danquah, L. Ginn, I. Herbinger, S. Jones, J. Junker, R. Kormos, C.Y. Kouakou, P. K. N'Goran, E. Normand, K. Shutt-

Phillips, A. Tickle, E. Vendras, A. Welsh, E.G. Wessling, C. BoeschThe critically endangered western chimpanzee declines by $80 \%$

Am. J. Primatol., 79 (2017)

https://doi.org/10.1002/ajp.22681

N.F. Kümpel, J.M. Rowcliffe, G. Cowlishaw, E.J. Milner-GullandTrapper profiles and strategies: insights into sustainability from hunter behaviour

Anim. Conserv., 12 (2009), pp. 531-539

https://doi.org/10.1111/j.1469-1795.2009.00279.x

C. Larrosa, L.R. Carrasco, E.J. Milner-GullandUnintended feedbacks: challenges and opportunities for improving conservation effectiveness

Conserv. Lett., 9 (2016), pp. 316-326

https://doi.org/10.1111/conl.12240

J.T.F. Lau, N.C.Y. Yeung, L.W.H. Mui, H.Y. Tsui, J. Gua simple new method to triangulate self-reported risk behavior data-the bean method

Sex. Transm. Dis., 38 (2011), pp. 788-792

https://doi.org/10.1097/OLQ.0b013e318218cc66

A.C. Luz, J. Paneque-Gálvez, M. Guèze, J. Pino, M.J. Macía, M. Orta-

Martínez, V. Reyes-GarcíaContinuity and change in hunting behaviour among contemporary indigenous peoples

Biol. Conserv., 209 (2017), pp. 17-26

https://doi.org/10.1016/j.biocon.2017.02.002

B.W. Miller, S.C. Caplow, P.W. LeslieFeedbacks between conservation and socialecological systems

Conserv. Biol., 26 (2012), pp. 218-227

https://doi.org/10.1111/j.1523-1739.2012.01823.x

E.J. Milner-GullandInteractions between human behaviour and ecological systems Philos. Trans. R. Soc. B Biol. Sci., 367 (2012), pp. 270-278

https://doi.org/10.1098/rstb.2011.0175

E.J. Milner-Gulland, M. Bakarr, H. Eves, J. Robinson, D. WilkieHunting the world's wildlife to extinction

Oryx, 36 (2002), pp. 328-329

https://doi.org/10.1017/S0030605302000637

R.A. Mittermeier, C.G. Mittermeier, T.M. Brooks, J.D. Pilgrim, W.R. Konstant, G.A. B. da Fonseca, C. KormosWilderness and biodiversity conservation

Proc. Natl. Acad. Sci., 100 (2003), pp. 10309-10313

https://doi.org/10.1073/pnas.1732458100 
C. Morsello, B. Yagüe, L. Beltreschi, N. Van

Vliet, C. Adams, T. Schor, M.P. Quiceno-Mesa, D. CruzCultural attitudes are stronger predictors of bushmeat consumption and preference than economic factors among urban amazonians from brazil and colombia

Ecol. Soc., 20 (2015)

https://doi.org/10.5751/ES-07771-200421

J. Nackoney, G. Molinario, P. Potapov, S. Turubanova, M.C. Hansen, T. FuruichiImp acts of civil conflict on primary forest habitat in northern Democratic Republic of the Congo, 1990-2010

Biol. Conserv., 170 (2014), pp. 321-328

https://doi.org/10.1016/j.biocon.2013.12.033

M.R. Nielsen, H. MeilbyHunting and trading bushmeat in the Kilombero Valley, Tanzania: Motivations, cost-benefit ratios and meat prices

Environ. Conserv., 42 (2015), pp. 61-72

https://doi.org/10.1017/S0376892914000198

M.R. Nielsen, H. Meilby, C. Smith-HallHow could the bushmeat trade in the

Kilombero Valley of Tanzania be regulated? Insights from the rural value chain Oryx, 50 (2016), pp. 84-93

https://doi.org/10.1017/S003060531400009X

E. Niesten, P. Zurita, S. BanksConservation agreements as a tool to generate direct incentives for biodiversity conservation

Biodiversity, 11 (2010), pp. 5-8

https://doi.org/10.1080/14888386.2010.9712639

A. Nuno, F.A.V. St JohnHow to ask sensitive questions in conservation: a review of specialized questioning techniques

Biol. Conserv., 189 (2014), pp. 5-15

https://doi.org/10.1016/j.biocon.2014.09.047

T.O. Nyumba, K. Wilson, C.J. Derrick, N. MukherjeeThe use of focus group

discussion methodology: insights from two decades of application in conservation Methods Ecol. Evol., 9 (2018), pp. 20-32

https://doi.org/10.1111/2041-210X.12860

J.F. Oates, M. Abedi-

lartey, W.S. Mcgraw, T.T. Struhsaker, G.H. Whitesides, T. Struhsaker, H. Whitesides Extinction of a West African red colobus monkey extinction of a West Afican red colobus monkey

Conserv. Biol., 14 (2010), pp. 1526-1532

W. Olupot, A.J. PlumptreAn Analysis of socioeconomics of bushmeat hunting at major hunting sites in Uganda

Work. Pap. no., 38 (2009), p. 108

I. Ordaz-

Németh, M. Arandjelovic, L. Boesch, T. Gatiso, T. Grimes, H.S. Kuehl, M. Lormie, C 
. Stephens, C. Tweh, J. JunkerThe socio-economic drivers of bushmeat consumption during the West African Ebola crisis

PLoS Negl. Trop. Dis., 11 (2017)

https://doi.org/10.1371/journal.pntd.0005450

M.D. Robards, M.L. Schoon, C.L. Meek, N.L. Engle The importance of social drivers in the resilient provision of ecosystem services

Glob. Environ. Chang., 21 (2011), pp. 522-529

https://doi.org/10.1016/j.gloenvcha.2010.12.004

\section{RoeTrading nature}

A Report, with Case Studies, on the Contribution of Wildlife Trade Management to Sustainable Livelihoods and the Millennium Development Goals, TRAFFIC International and WWF International, Cambridge, UK (2008)

D. Roe, F. Booker, M. Day, W. Zhou, S. Allebone-

Webb, N.A.O. Hill, N. Kumpel, G. Petrokofsky, K. Redford, D. Russell, G. Shepherd, J. Wright, T.C.H. SunderlandAre alternative livelihood projects effective at reducing local threats to specified elements of biodiversity and/or improving or maintaining the conservation status of those elements?

Environ. Evid., 4 (22) (2015)

https://doi.org/10.1186/s13750-015-0048-1

B. Schulte-Herbrüggen, G. Cowlishaw, K. Homewood, J.M. RowcliffeThe importance of bushmeat in the livelihoods of West African cash-crop farmers living in a faunally-depleted landscape

PLoS One, 8 (2013), pp. 1-13

https://doi.org/10.1371/journal.pone.0072807

H. Smith, S. Marrocoli, A.G. Lozano, X. BasurtoHunting for common ground between wildlife governance and commons scholarship

Conserv. Biol., 33 (2019), pp. 9-21

https://doi.org/10.1111/cobi.13200

G. Taylor, J.P.W. Scharlemann, M. Rowcliffe, N. Kümpel, M.B.J. Harfoot, J.E. Fa, R. Melisch, E.J. Milner-

Gulland, S. Bhagwat, K.A. Abernethy, A.S. Ajonina, L. Albrechtsen, S. AlleboneWebb, E. Brown, D. Brugiere, C. Clark, M. Colell, G. Cowlishaw, D. Crookes, E. De Merode, J. Dupain, T. East, D. Edderai, P. Elkan, D. Gill, E. Greengrass, C. Hodgkins on, O. Ilambu, P. Jeanmart, J. Juste, J.M. Linder, D.W. Macdonald, A.J. Noss, P.U. O korie, V.J.J. Okouyi, S. Pailler, J.R. Poulsen, M. Riddell, J. Schleicher, B. SchulteHerbrüggen, M. Starkey, N. Van

Vliet, C. Whitham, A.S. Willcox, D.S. Wilkie, J.H. Wright, L.M. CoadSynthesising bushmeat research effort in West and Central Africa: a new regional database Biol. Conserv., 181 (2015), pp. 199-205

https://doi.org/10.1016/j.biocon.2014.11.001

S. Tranquilli, M. Abedi-

Lartey, K. Abernethy, F. Amsini, A. Asamoah, C. Balangtaa, S. Blake, E. Bouanga, T . Breuer, T.M. Brncic, G. Campbell, R. Chancellor, C.A. Chapman, T.R.B. Davenport 
, A. Dunn, J. Dupain, A. Ekobo, M. Eno-

Nku, G. Etoga, T. Furuichi, S. Gatti, A. Ghiurghi, C. Hashimoto, J.A. Hart, J. Head, M. Hega, I. Herbinger, T.C. Hicks, L.H. Holbech, B. Huijbregts, H.S. Kühl, I. Imong, S.L.D. Yeno, J. Linder, P. Marshall, P.M. Lero, D. Morgan, L. Mubalama, P.K. N'Gor an, A. Nicholas, S. Nixon, E. Normand, L. Nziguyimpa, Z. Nzooh-Dongmo, R. OforiAmanfo, B.G. Ogunjemite, C.A. Petre, H.J. Rainey, S. Regnaut, O. Robinson, A. Run dus, C.M. Sanz, D.T. Okon, A. Todd, Y. Warren, V. SommerProtected areas in tropical Africa: assessing threats and conservation activities PLoS One, 9 (2014), pp. 1-21 https://doi.org/10.1371/journal.pone.0114154

C.G. Tweh, M.M. Lormie, C.Y. Kouakou, A. Hillers, H.S. Kühl, J. JunkerConservati on status of chimpanzees Pan troglodytes verus and other large mammals in Liberia: a nationwide survey Oryx, 49 (2014), pp. 710-718 https://doi.org/10.1017/S0030605313001191

N. Van Vliet, M.P. Quiceno-mesa, D. Cruz-antia, L. Jonhson, N. De Aquino, J. Moreno, R. NasiThe uncovered volumes of bushmeat commercialized in the Amazonian trifrontier between Colombia, Peru \& Brazil Ethnobiol. Conserv., 7 (2014), pp. 1-11 https://doi.org/10.15451/ec2014-11-3.7-1-11

N. Van Vliet, M.P. Quiceno, D. Cruz, L.J. Neves de Aquino, B. Yagüe, T. Schor, S. Hernandez, R. NasiBushmeat networks link the forest to urban areas in the trifrontier region between Brazil, Colombia, and Peru

Ecol. Soc., 20 (2015)

$\operatorname{art} 21$

https://doi.org/10.5751/ES-07782-200321

B. Vollan, S. Prediger, M. FrölichCo-managing common-pool resources: Do formal rules have to be adapted to traditional ecological norms?

Ecol. Econ., 95 (2013), pp. 51-62

https://doi.org/10.1016/j.ecolecon.2013.08.010

G. Walters, J. Schleicher, O. Hymas, L. CoadEvolving hunting practices in gabon: lessons for community-based conservation interventions

Ecol. Soc., 20 (2015)

https://doi.org/10.5751/ES-08047-200431

S. Wicander, L. CoadLearning Our Lessons: A Review of Alternative Livelihood Projects in Central Africa

Oxford

https://doi.org/10.2305/IUCN.CH.2015.01.en (2015)

J.H. Wright, N.A.O. Hill, D. Roe, J.M. Rowcliffe, N.F. Kümpel, M. Day, F. Booker, E.J. Milner-GullandReframing the concept of alternative livelihoods

Conserv. Biol., 30 (2016), pp. 7-13

https://doi.org/10.1111/cobi.12607 
